SUPPORTING INFORMATION PARAGRAPH

\title{
Chemoselectively Addressable Template: a valuable tool for the engineering of molecular conjugates
}

Elisabeth Garanger, Didier Boturyn, ${ }^{*}$ Olivier Renaudet, Eric Defrancq and Pascal Dumy ${ }^{*}$

Table of contents :

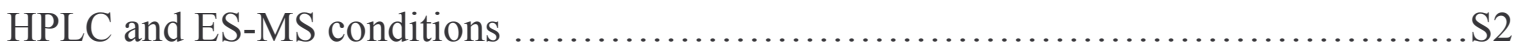

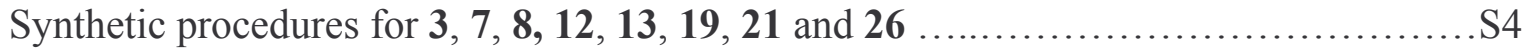

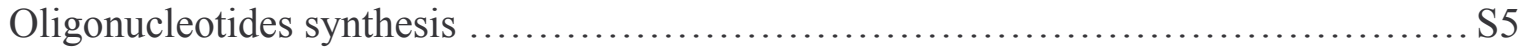

RP-HPLC chromatogram and ES-MS spectrum of 1 ............................. S6

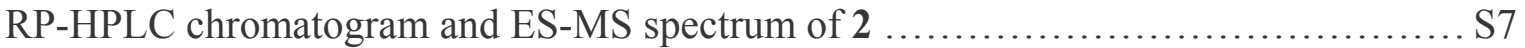

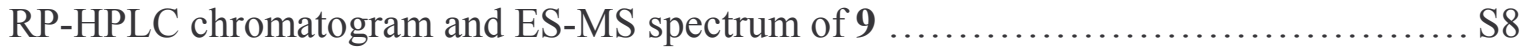

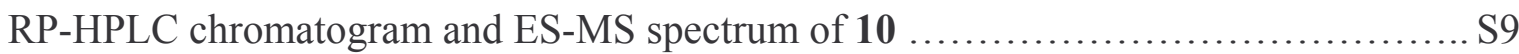

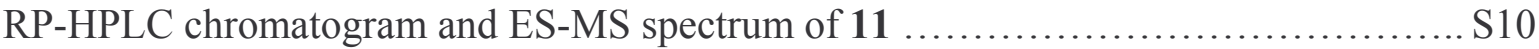

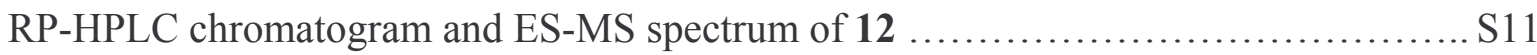

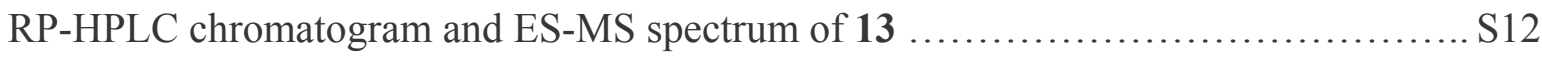

RP-HPLC chromatogram and ES-MS spectrum of 17 ...................................

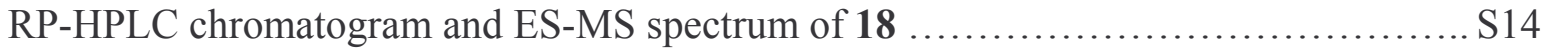

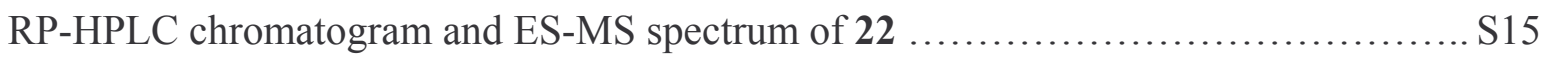

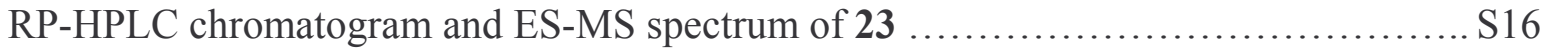

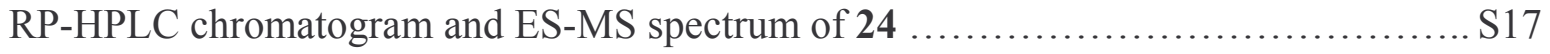

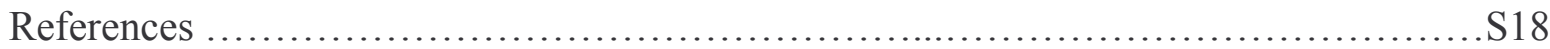




\section{HPLC and ES-MS conditions.}

The purity of peptide derivatives was controlled by RP-HPLC on analytical columns and UV monitoring at $214 \mathrm{~nm}$. Solvent A consisted in $0.09 \%$ TFA in water and solvent B in $0.09 \%$ TFA/9.91\% $\mathrm{H}_{2} \mathrm{O}$ in acetonitrile. A preparative column (100 $\AA 15 \mu \mathrm{m} \mathrm{C}_{18}$ particles, 200x2.5 $\mathrm{mm}$ ) was used to purify crude peptides (when necessary). Purifications were realized using the previous solvent system and a flow rate of $22 \mathrm{~mL} \cdot \mathrm{min}^{-1}$. Oligonucleotides were purified on a specific column ( $7 \mu \mathrm{m} \mathrm{C}_{18}$ particles, $\left.10 \times 250 \mathrm{~mm}\right)$ using the following conditions: solvent $\mathrm{A}, 20$ mM ammonium acetate buffer/ $\mathrm{CH}_{3} \mathrm{CN}, 95: 5$ (v:v); solvent $\mathrm{B}, \mathrm{CH}_{3} \mathrm{CN}$; flow rate, $4 \mathrm{~mL} \cdot \mathrm{min}^{-1}$; linear gradient, 0 to $30 \% \mathrm{~B}$ in $20 \mathrm{~min}$.

Gradient conditions were :

- Conditions A : Analytical column (120 ̊ $3 \mu \mathrm{m} \mathrm{C}_{18}$ particles, 30x4.6 mm); flow rate, 1.3 mL. min $^{-1}$; linear gradient, 5 to $60 \%$ of $\mathrm{B}$ in $15 \mathrm{~min}$.

- Conditions B : Analytical column (100 5 $5 \mathrm{~m} \mathrm{C}_{18}$ particles, 250x4.6 mm); flow rate, 1.0 mL. $\mathrm{min}^{-1}$; linear gradient, 5 to $60 \%$ of $\mathrm{B}$ in $30 \mathrm{~min}$.

- Conditions C : Analytical column (100 5 $5 \mathrm{~m} \mathrm{C}_{18}$ particles, 250x4.6 mm); flow rate, 1.0 $\mathrm{mL} \cdot \mathrm{min}^{-1}$; linear gradient, 5 to $100 \%$ of $\mathrm{B}$ in $30 \mathrm{~min}$.

- Conditions D : Analytical column (120 $\AA 3 \mu \mathrm{m} \mathrm{C}_{18}$ particles, 30x4.6 mm); flow rate, 1.3 mL. min $^{-1}$; linear gradient, 5 to $100 \%$ of $\mathrm{B}$ in $15 \mathrm{~min}$.

- Conditions E : Analytical column (120 $\AA 3 \mu \mathrm{m} \mathrm{C}_{18}$ particles, 30x4.6 mm); flow rate, 1.3 mL.min ${ }^{-1}$; linear gradient, 5 to $40 \%$ of B in 15 min.

- Conditions F : Analytical column (100 $55 \mu \mathrm{m} \mathrm{C}_{18}$ particles, 250x4.6 mm); flow rate, 1.0 mL. $\min ^{-1}$; linear gradient, 5 to $40 \%$ of $\mathrm{B}$ in $30 \mathrm{~min}$. 
ESI-Mass Spectra were recorded in the positive mode for peptide derivatives using aqueous acetonitrile as eluent and in the negative mode for oligonucleotides using $50 \%$ aqueous acetonitrile and $2 \% \mathrm{NEt}_{3}$ as eluent. 


\section{Synthetic procedures for $3,7,8,12,13,19,21$ and 26 :}

Peptide 3 : This peptide was synthesized according to a reported procedure. ${ }^{1}$ Mass spectrum (ES-MS, positive mode) calcd 1646.0, found 1646.1.

Peptide 7 : RGD containing-peptides 7 was obtained as described earlier. ${ }^{2}$

Peptide 8 : containing-peptides 8 was obtained as described earlier. ${ }^{2}$

Peptide conjugate 12 : RGD-containing peptide $7(4.4 \mathrm{mg}, 6.7 \mu \mathrm{mol})$ was added to a solution of peptide $2(5 \mathrm{mg}, 3 \mu \mathrm{mol})$ in $800 \mu \mathrm{L}$ of $0.1 \mathrm{M} \mathrm{AcO} \mathrm{Na}^{+}, \mathrm{pH} 4.6: \mathrm{CH}_{3} \mathrm{CN}$ (1:1). After 6 h., sodium periodate $(13 \mathrm{mg}, 60 \mu \mathrm{mol})$ was added to it. The reaction mixture was stirred for 1 h. and then purified by RP-HPLC to obtain compound $\mathbf{1 2}$ as white powder $(5.1 \mathrm{mg}, 1.8 \mu \mathrm{mol}$, $61 \%$ overall yield). Mass spectrum (ES-MS, positive mode) calcd 2802.0, found 2801.3

Peptide conjugate 13 : RGD-containing peptide $8(1.2 \mathrm{mg}, 1.3 \mu \mathrm{mol})$ was added to a solution of peptide $12(0.8 \mathrm{mg}, 0.29 \mu \mathrm{mol})$ in $200 \mu \mathrm{L}$ of $0.1 \mathrm{M} \mathrm{AcO}^{-} \mathrm{Na}^{+}, \mathrm{pH} 4.6 / \mathrm{CH}_{3} \mathrm{CN}(1: 1)$. After 4 days, the product was purified by RP-HPLC to obtain compound $\mathbf{1 3}$ as a white powder (1.2 mg, $0.22 \mu \mathrm{mol}, 76 \%$ overall yield). Mass spectrum (ES-MS, positive mode) calcd 5436.9, found 5437.6.

Peptide 19 : This peptide was synthesized as described in the literature. ${ }^{1}$ Mass spectrum (ES-MS, positive mode) calcd 1504.8, found 1504,9.

Oligonucleotide 21 : The synthesis of this oligonucleotide was prepared as described earlier. ${ }^{3}$ Mass spectrum (ES-MS, negative mode) calcd 4962.0, found 4961.7.

Polylysine peptide 26 : This compound was synthesized following the chemical scheme described in literature. ${ }^{4}$ 


\section{Oligonucleotides synthesis.}

Automated DNA synthesis was carried out on an Expedite DNA synthesizer by using standard $\beta$-cyanoethyl nucleoside phosphoramidites chemistry on a $1 \mu \mathrm{M}$ scale with final DMT on. Oligonucleotides were cleaved from the solid support by treatment with $28 \%$ ammonia solution for $2 \mathrm{~h}$ and finally deprotected by keeping the ammonia solution at $55^{\circ} \mathrm{C}$ for $16 \mathrm{~h}$. The 5'-protected oligonucleotides carrying the 5'-trityl protected aminooxy were purified by RPHPLC and characterized by ES-MS. 


\section{RP-HPLC chromatogram and ES-MS spectrum of 1.}

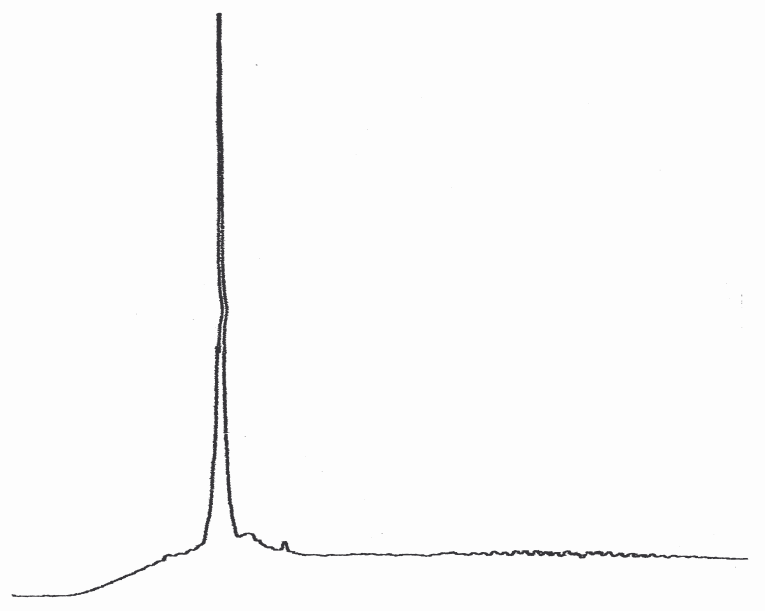

Figure S1: RP-HPLC chromatogram of $\mathbf{1}$ (Retention Time $=13.6 \mathrm{~min}$, conditions C).

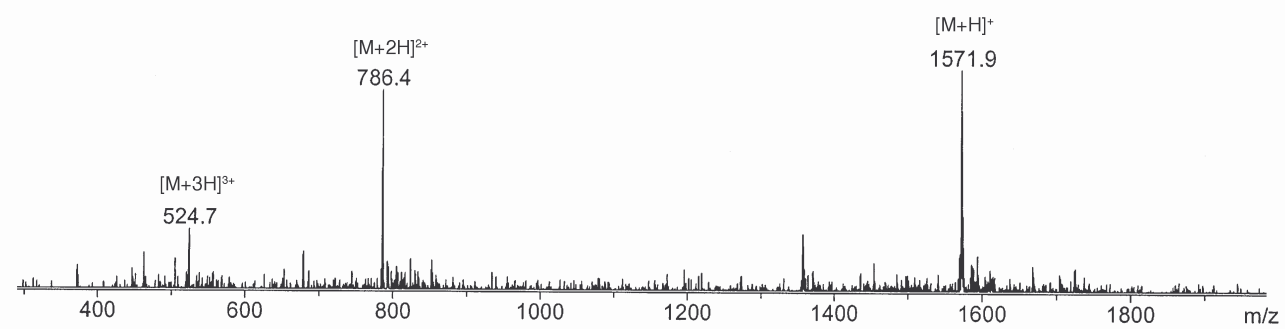

Figure S2: ES-MS spectrum of $\mathbf{1 .}$ 
RP-HPLC chromatogram and ES-MS spectrum of 2.

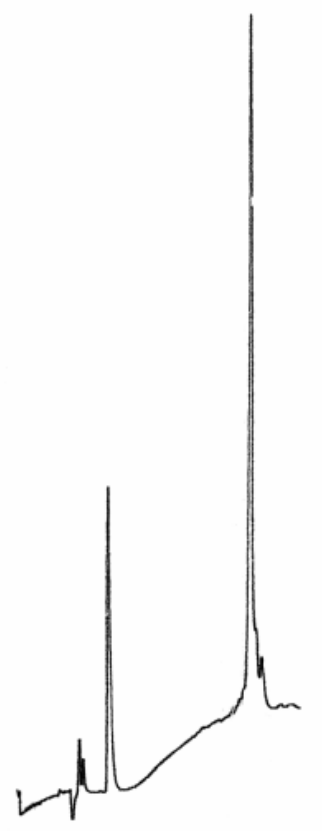

Figure S3: RP-HPLC chromatogram of 2 (Retention Time $=14.7$ min, conditions F).

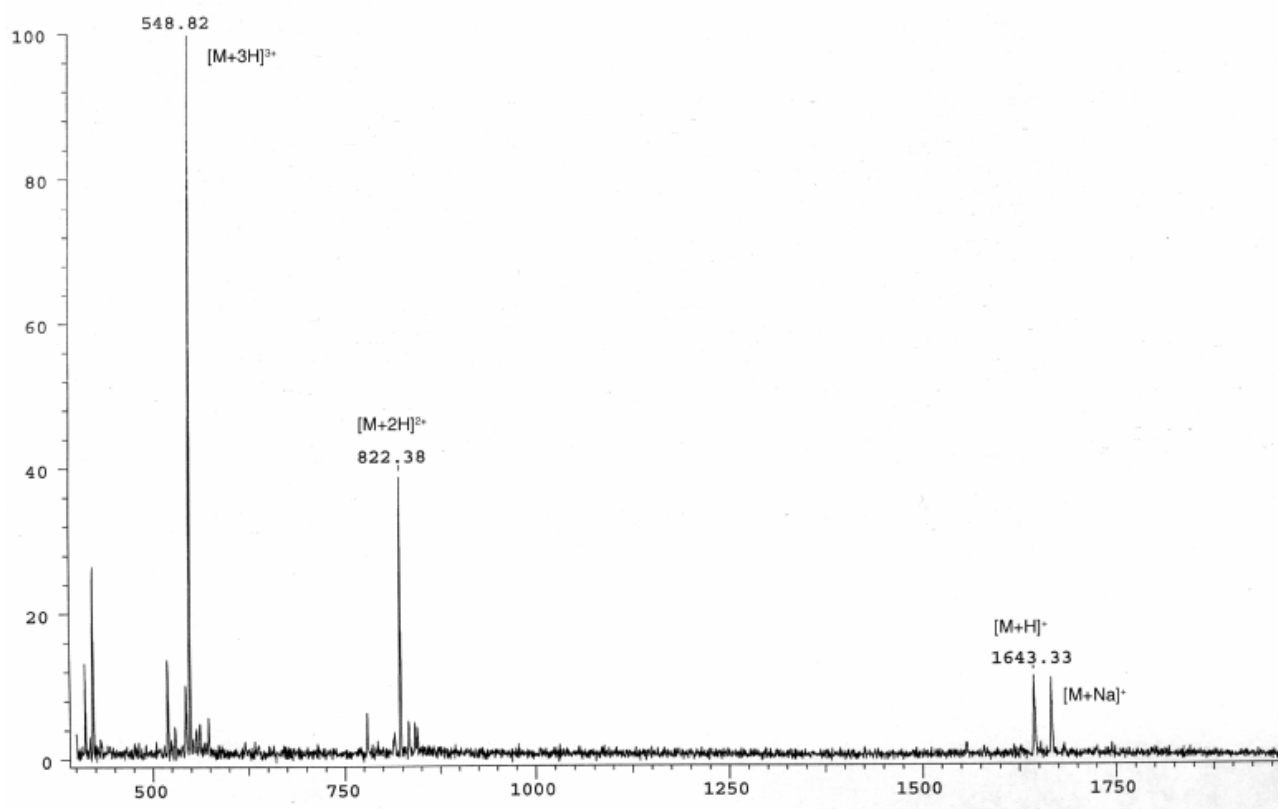

Figure S4: ES-MS spectrum of 2. 


\section{RP-HPLC chromatogram and ES-MS spectrum of 9}

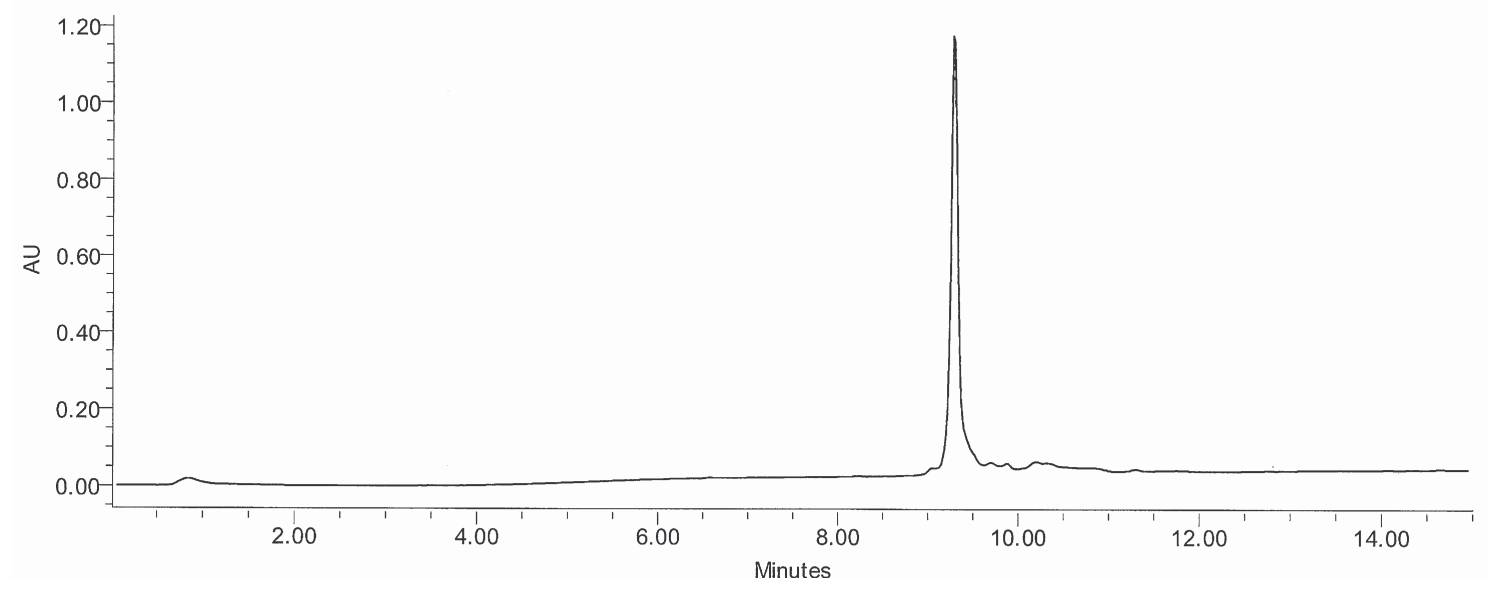

Figure S5: RP-HPLC chromatogram of 9 (Retention Time $=9.3$ min, conditions A).

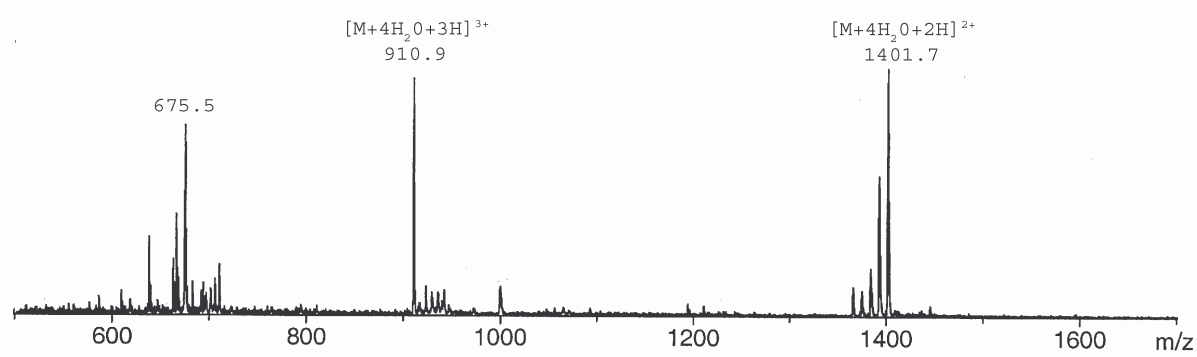

Figure S6: ES-MS spectrum of 9. 
RP-HPLC chromatogram and ES-MS spectrum of 10.

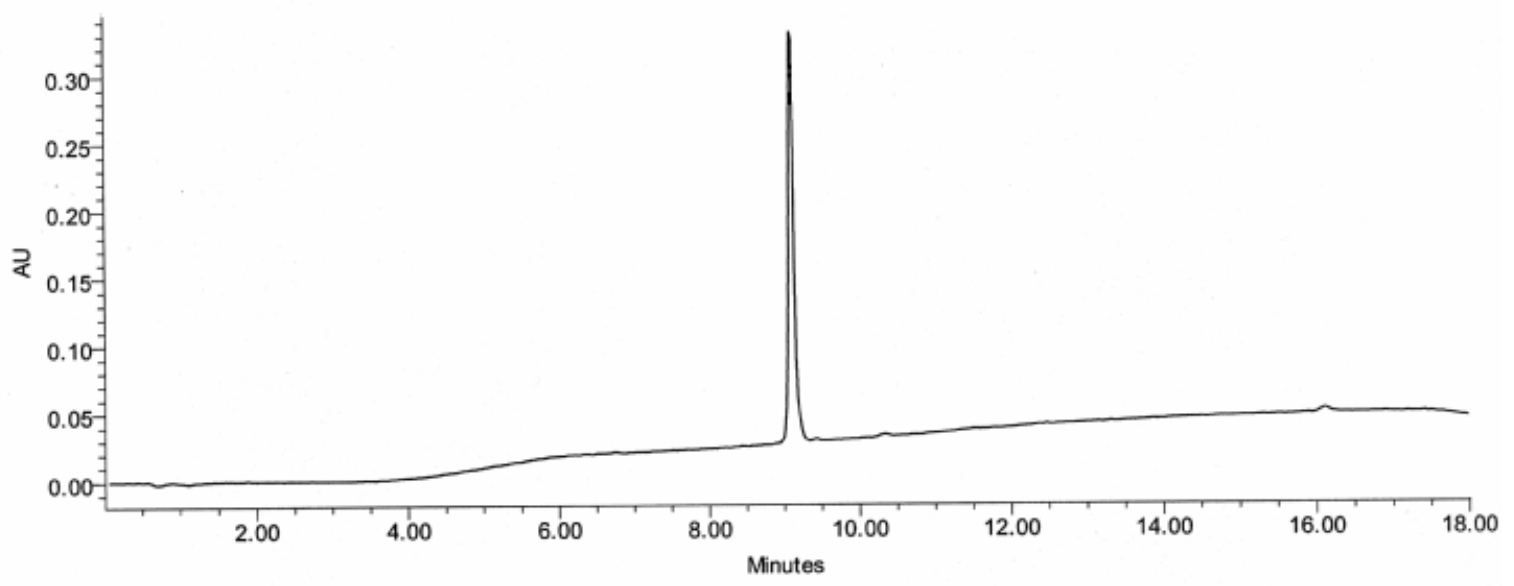

Figure S7: RP-HPLC chromatogram of $\mathbf{1 0}$ (Retention Time $=10.7 \mathrm{~min}$, conditions A).

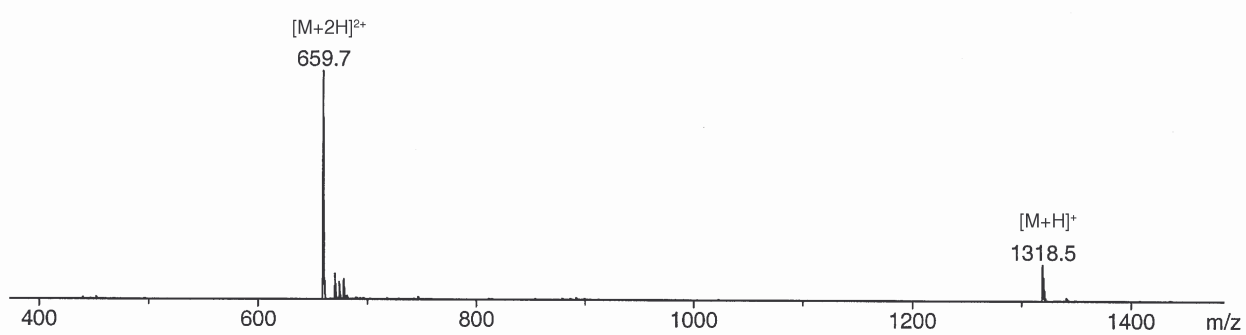

Figure S8: ES-MS spectrum of $\mathbf{1 0 .}$ 
RP-HPLC chromatogram and ES-MS spectrum of 11.

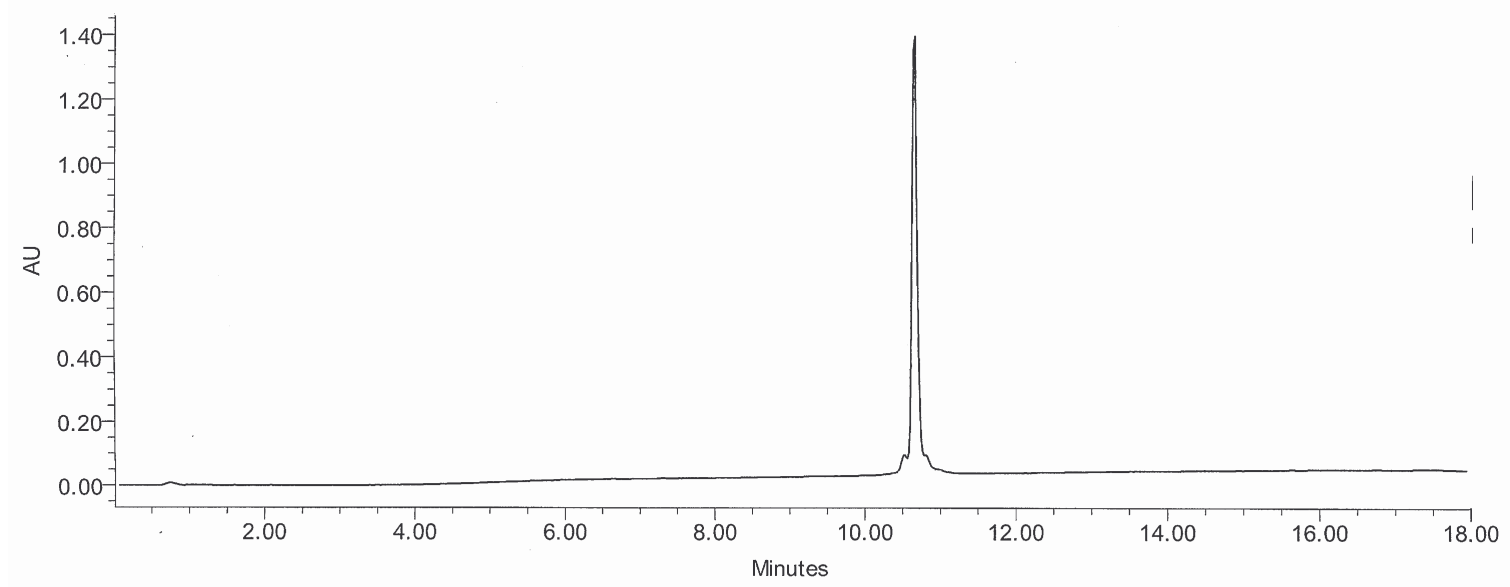

Figure S9: RP-HPLC chromatogram of 11 (Retention Time $=10.7$ min, conditions A).

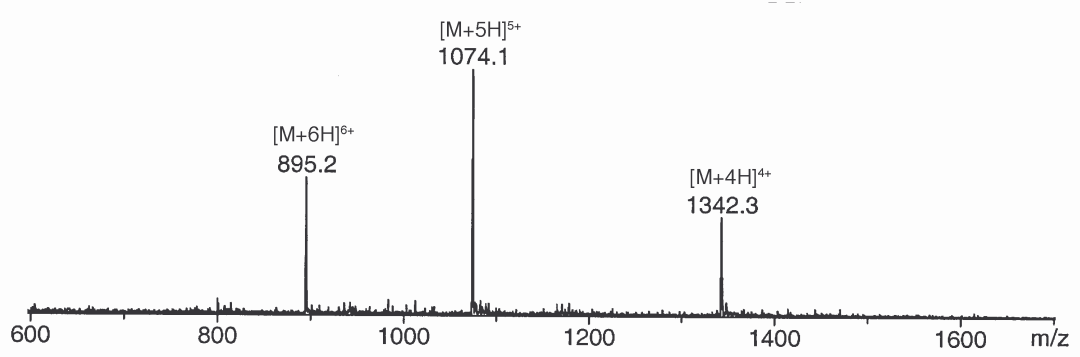

Figure S10: ES-MS spectrum of 11. 


\section{RP-HPLC chromatogram and ES-MS spectrum of 12.}

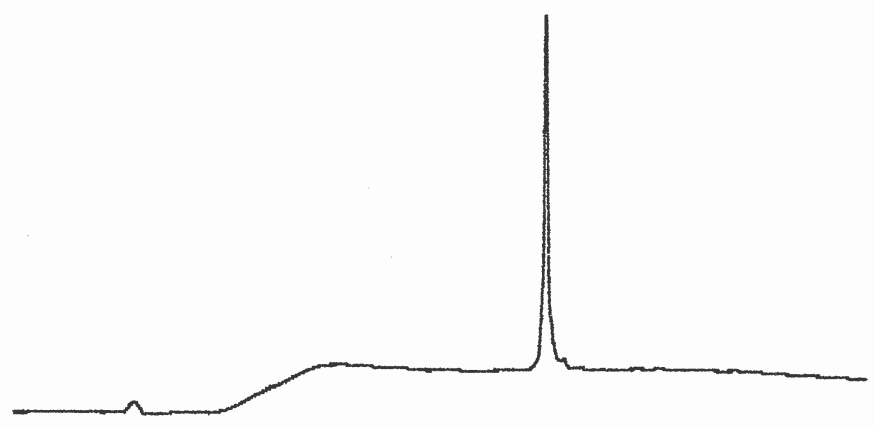

Figure S11: RP-HPLC chromatogram of 12 (Retention Time $=21.8$ min, conditions B).

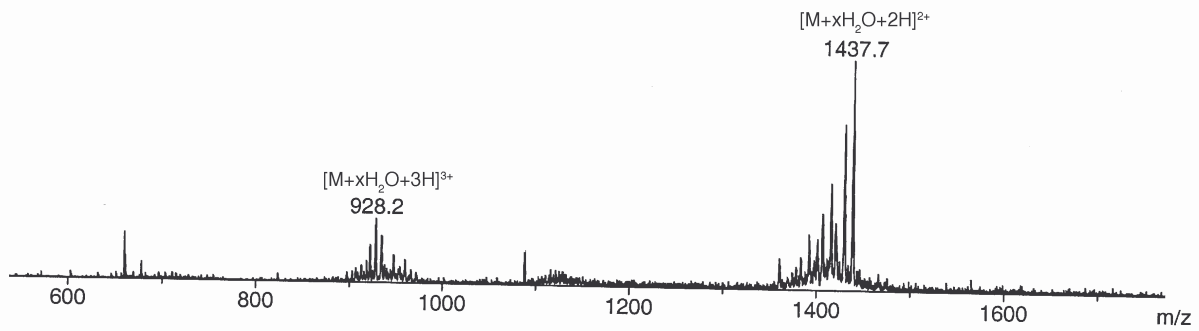

Figure S12: ES-MS spectrum of 12. 


\section{RP-HPLC chromatogram and ES-MS spectrum of 13.}

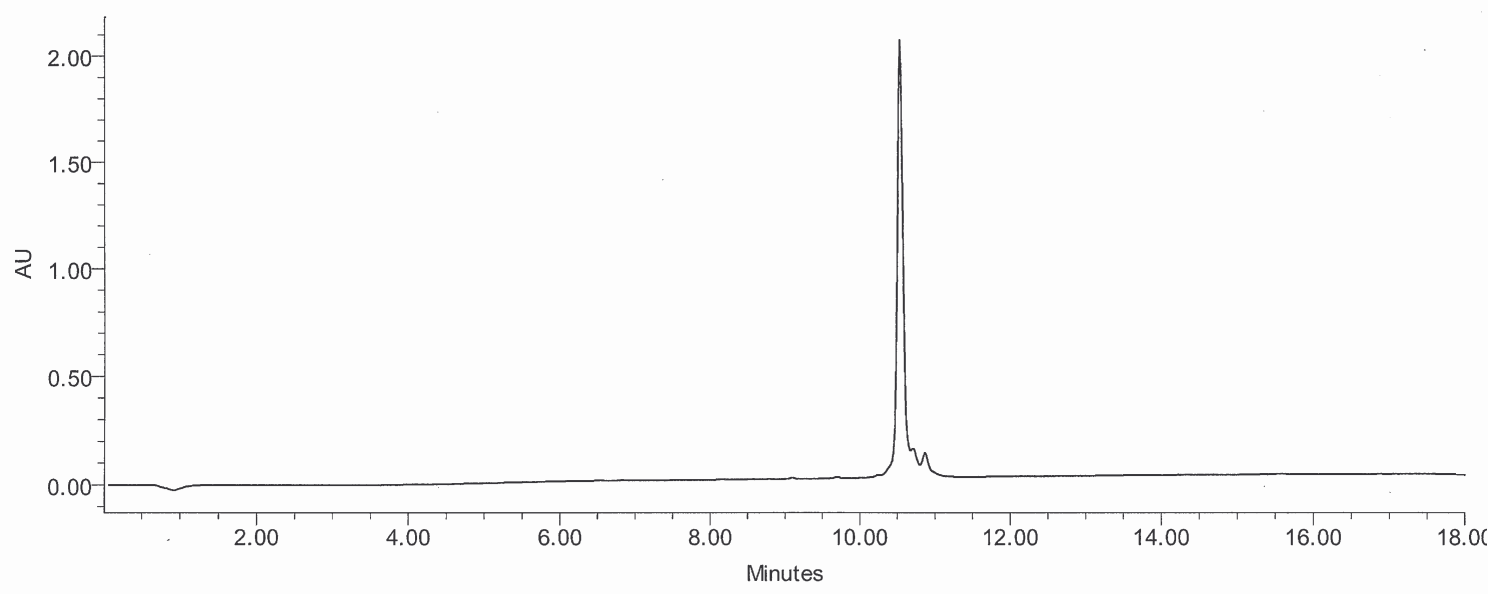

Figure S13: RP-HPLC chromatogram of $\mathbf{1 3}$ (Retention Time $=10.5 \mathrm{~min}$, conditions A).

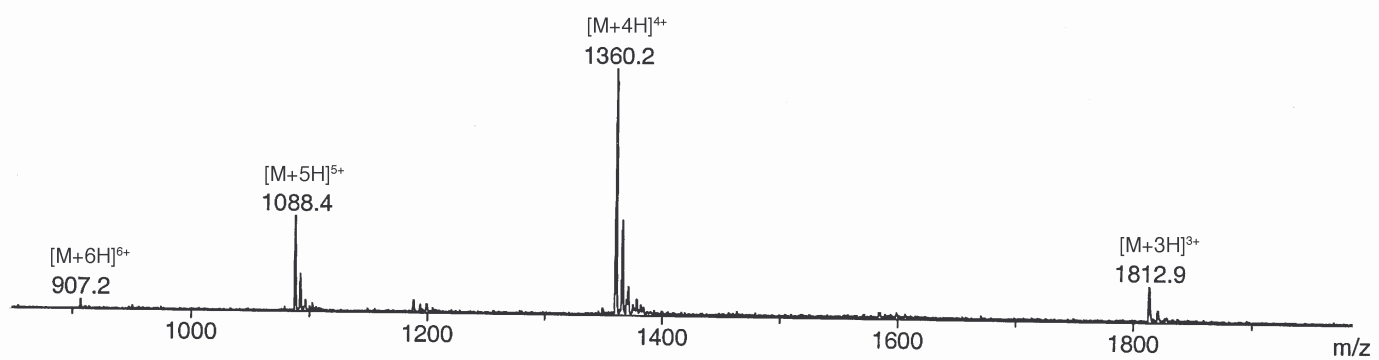

Figure S14: ES-MS spectrum of 13. 


\section{RP-HPLC chromatogram and ES-MS spectrum of 17.}

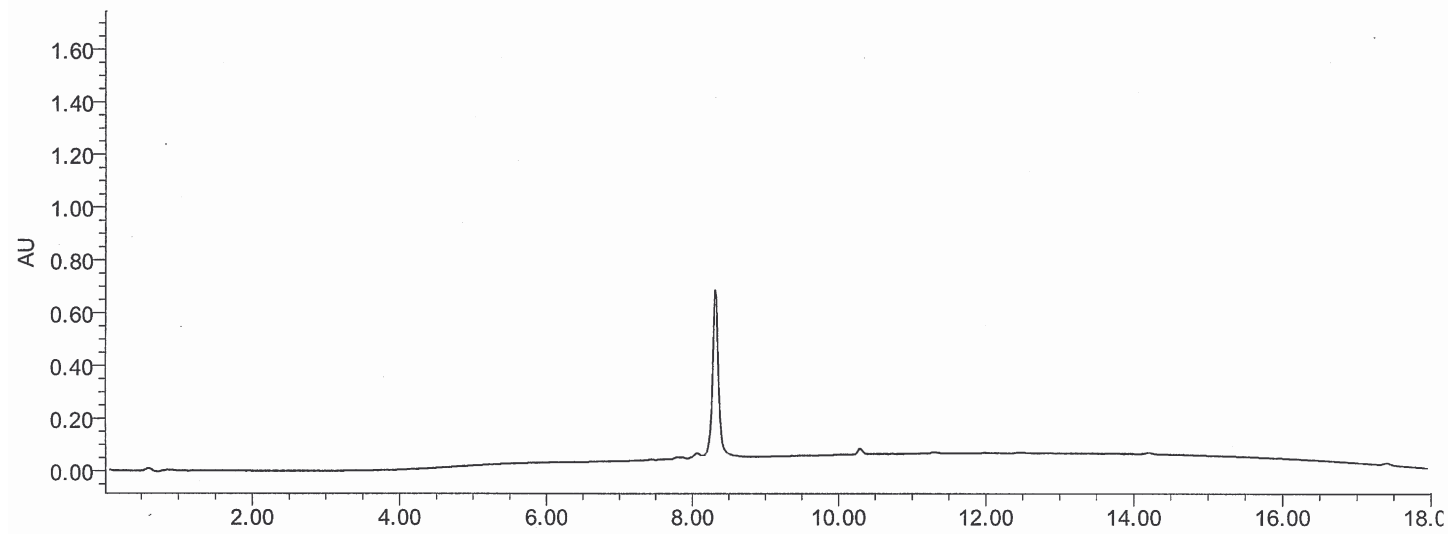

Figure S15: RP-HPLC chromatogram of 17 (Retention Time $=8.3$ min, conditions D).

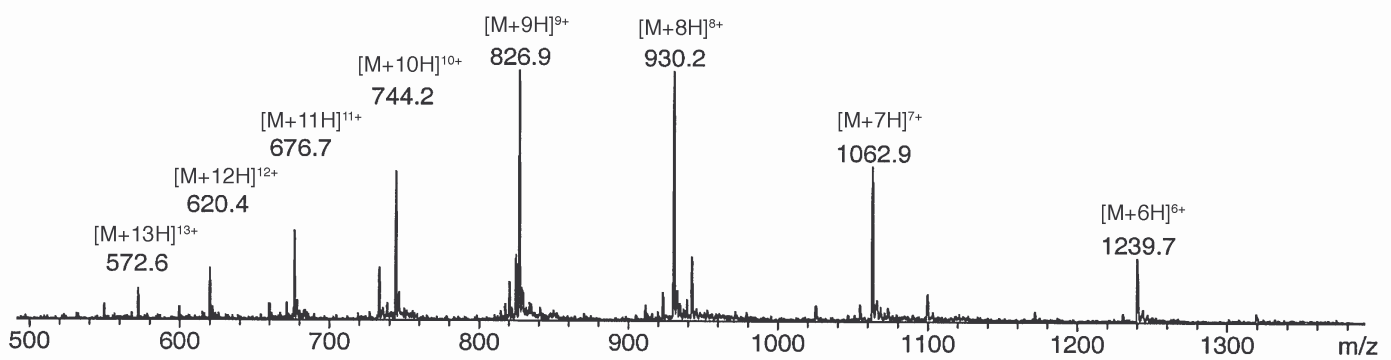

Figure S16: ES-MS spectrum of 17. 
RP-HPLC chromatogram and ES-MS spectrum of 18.

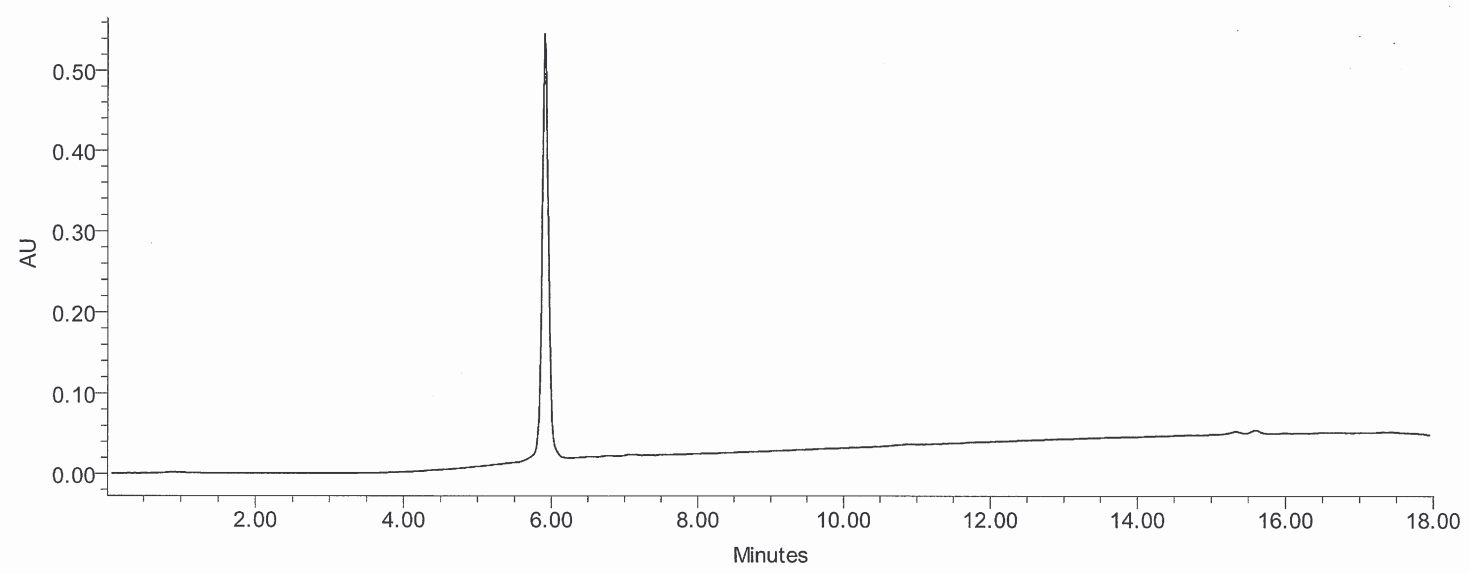

Figure S17: RP-HPLC chromatogram of $\mathbf{1 8}$ (Retention Time $=5.9$ min, conditions A).

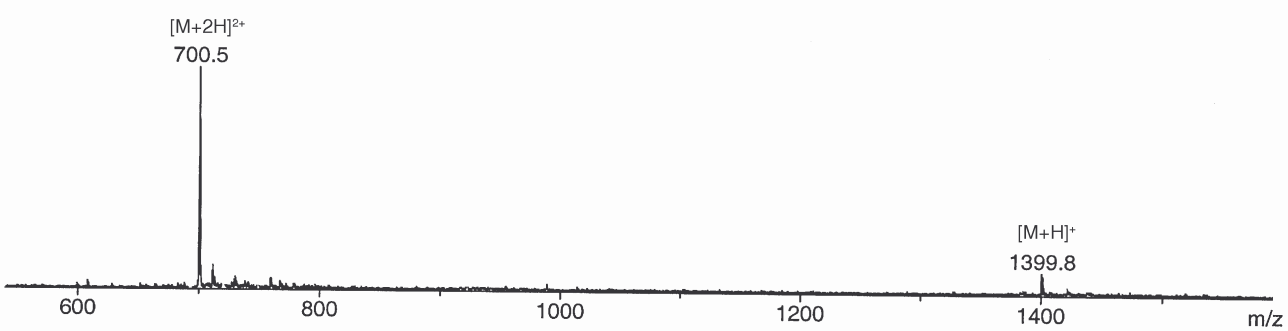

Figure S18: ES-MS spectrum of 18. 
RP-HPLC chromatogram and ES-MS spectrum of 22.

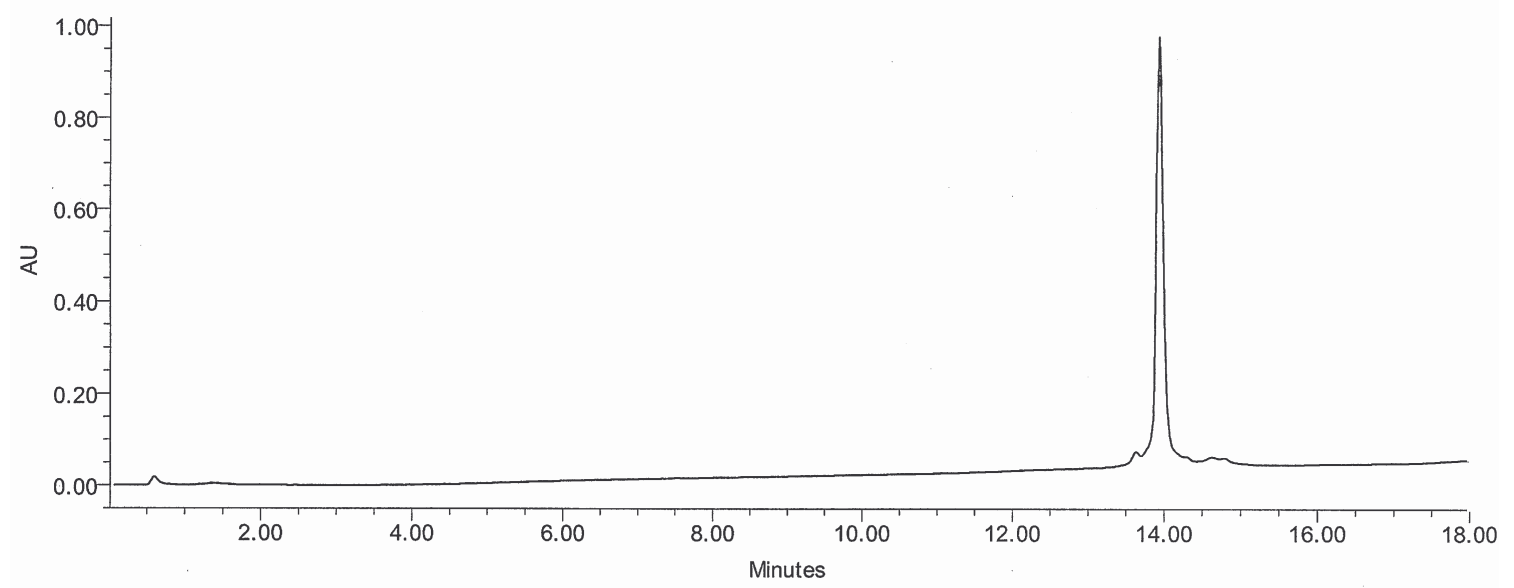

Figure S19: RP-HPLC chromatogram of 22 (Retention Time $=14.0$ min, conditions E).

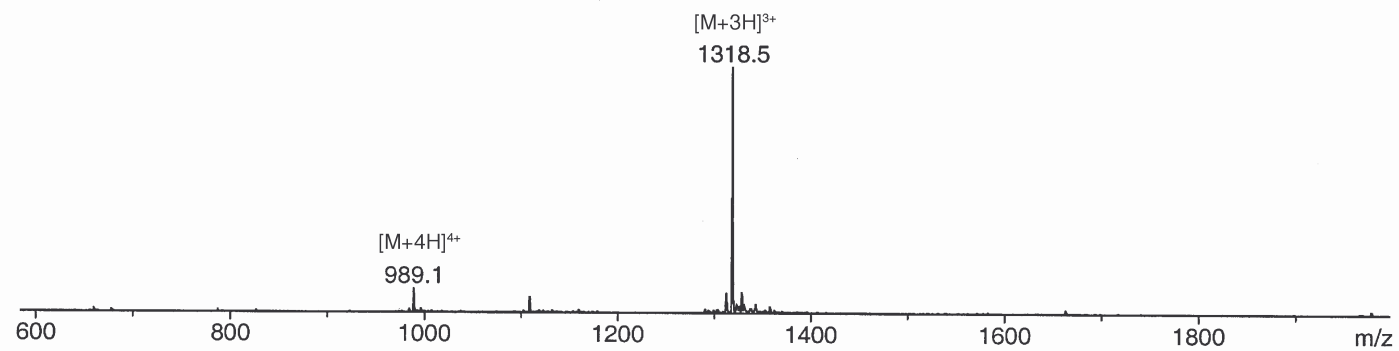

Figure S20: ES-MS spectrum of 22. 
RP-HPLC chromatogram and ES-MS spectrum of 23.

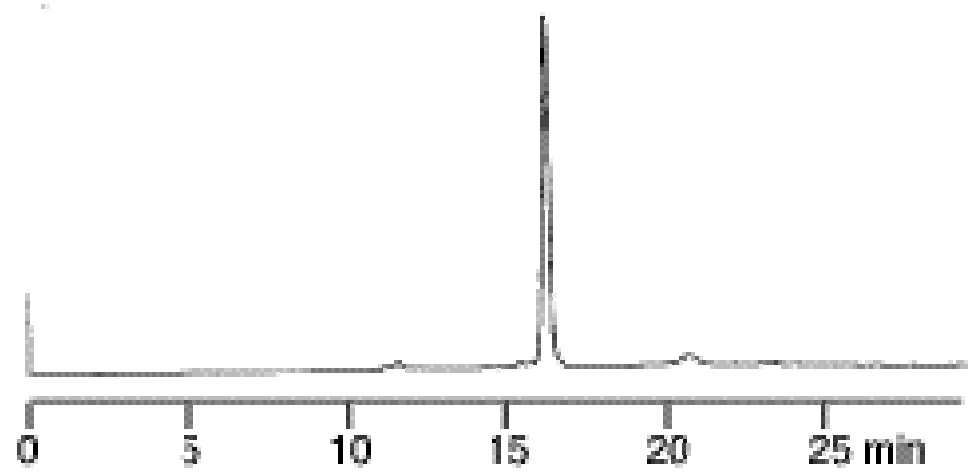

Figure S21: RP-HPLC chromatogram of 23 (Retention Time $=14.0$ min, conditions F).

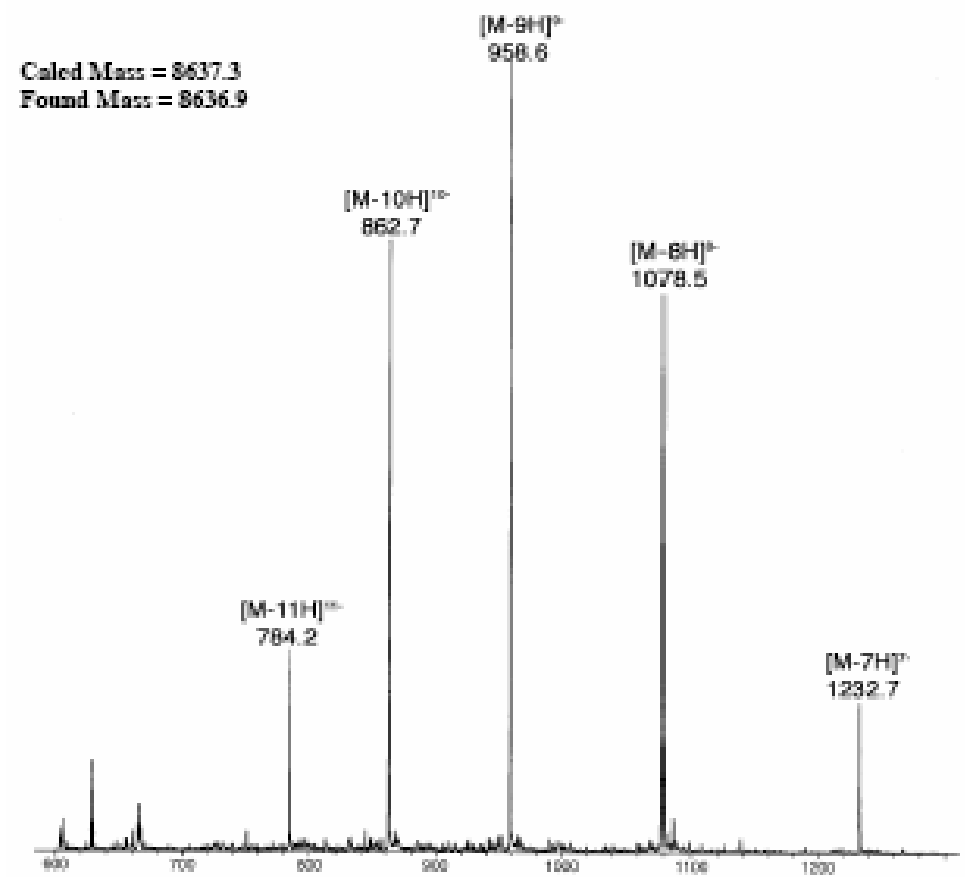

Figure S22: ES-MS spectrum of 23. 
RP-HPLC chromatogram and ES-MS spectrum of 24.

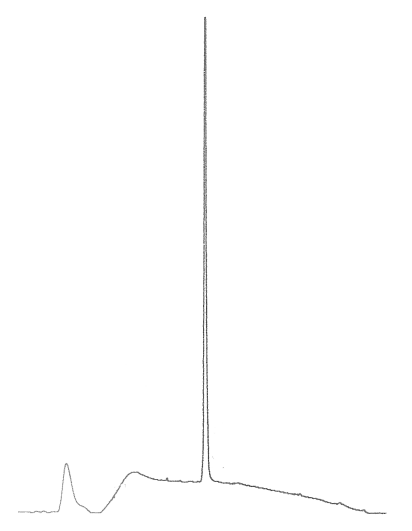

Figure S23: RP-HPLC chromatogram of $\mathbf{2 4}$ (Retention Time $=18.4 \mathrm{~min}$, conditions C).

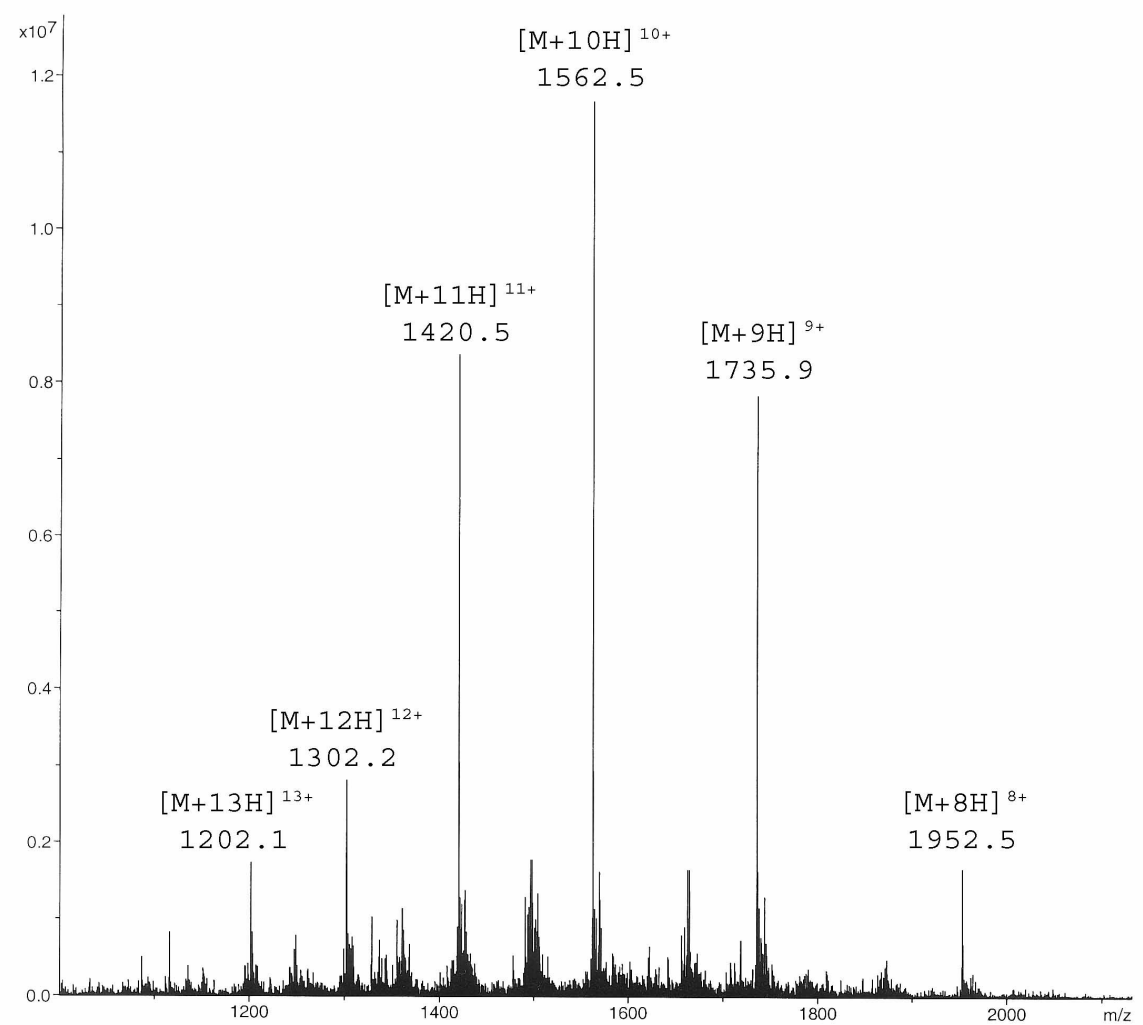

Figure S24: ES-MS spectrum of 24. 


\section{References :}

${ }^{1}$ Boturyn, D.; Coll, J.-L.; Garanger, E.; Favrot, M.-C.; Dumy, P. J. Am. Chem. Soc. 2004, 126, 5730-5739.

${ }^{2}$ Boturyn, D.; Dumy, P. Tetrahedron Lett. 2001, 42, 2787-2790.

${ }^{3}$ Forget, D.; Boturyn, D.; Defrancq, E.; Lhomme, J.; Dumy, P. Chem. Eur. J. 2001, 7, 3976-3984.

${ }^{4}$ Shao, J.; Tam, J.-P. J. Am. Chem. Soc. 1995, 117, 3893-3899. 